\title{
Protein Modification at Tyrosine with Iminoxyl Radicals
}

\author{
Katsuya Maruyama, Takashi Ishiyama, Yohei Seki, Kentaro Sakai, Takaya Togo, Kounosuke Oisaki*, \\ Motomu Kanai*
}

Graduate School of Pharmaceutical Sciences, The University of Tokyo, 7-3-1 Hongo, Bunkyo-ku, Tokyo 113-0033, Japan

KEYWORDS: Tyrosine, Bioconjugation, Reversible, Protein, Iminoxyl Radical.

\begin{abstract}
Post-translational modifications (PTMs) of proteins are a biological mechanism for reversibly controlling protein function. Synthetic protein modifications (SPMs) at specific canonical amino acids can mimic PTMs. However, reversible SPMs at hydrophobic amino acid residues in proteins are especially limited. Here we report a tyrosine (Tyr)-selective SPM utilizing persistent iminoxyl radicals, which are readily generated from sterically hindered oximes via single electron oxidation. The reactivity of iminoxyl radicals with Tyr was dependent on the steric and electronic demands of oximes; isopropyl methyl piperidinium oxime 1f formed stable adducts, whereas the reaction of tert-butyl methyl piperidinium oxime 10 was reversible. The difference in reversibility between $\mathbf{1 f}$ and 1o, differentiated only by one methyl group, is due to the stability of iminoxyl radicals, which is partly dictated by the bond dissociation energy of oxime O-H groups. The Tyr-selective modifications with $\mathbf{1}$ f and $\mathbf{1 o}$ proceeded under physiologicallyrelevant, mild conditions. Specifically, the stable Tyr-modification with $\mathbf{1 f}$ introduced functional small molecules, including an azobenzene photoswitch, to proteins, whereas the reversible modification of Tyr with 10 switched protein function on and off in an enzyme and in a monoclonal antibody by modification and deconjugation processes.
\end{abstract}

\section{Introduction}

Life emerges from dynamic chemical networks of biomolecules. $^{1,2}$ Together with the one-way information flow from DNA to RNA and proteins (the central dogma), the biochemical order of life is also governed by reversible, enzymatic posttranslational modifications (PTMs) of biomacromolecules. ${ }^{3}$ Lysine acylation/deacylation ${ }^{4,5}$ and serine/threonine/tyrosine phosphorylation/dephosphorylation ${ }^{6-8}$ are typical examples of reversible PTMs at protein levels. Inspired by nature's PTMs, methodologies for synthetic protein modifications (SPMs) are emerging, aimed at creating novel biomaterials, therapeutics, and diagnoses through in vitro reactions ${ }^{9-13}$ and understanding and intervening into biological mechanisms through in vivo reactions. ${ }^{14,15}$ Although nucleophilic amino acids, such as Lys and Cys, have been the main SPM sites, recent endeavors are expanding to target chemically more-inert amino acids Tyr, ${ }^{16,17}$ Trp,${ }^{18}$ Met, ${ }^{19-21}$ His, ${ }^{22-24}$ and Ser. ${ }^{25}$ This new trend in synthetic organic chemistry will vastly broaden both accessible chemical space and the potential functions of protein-based molecules with high structural homogeneity.

Reversible SPMs, mimicking biochemical PTMs, however, remain less explored. Examples of reversible SPMs have been mostly limited to Michael addition/retro-Michael reaction ${ }^{26-34}$ or alkylation/dealkylation at $\mathrm{Cys}^{35-37}$; nevertheless, this chemistry has recently expanded to $\mathrm{His}^{38}$ (Figure 1a). The use of a $\mathrm{pH}$ sensitive linker ${ }^{39,40}$ and dynamic imine formation ${ }^{41-47}$ at Lys have been demonstrated more recently, the latter of which was extended to $N$-terminal Cys modifications ${ }^{48,49}$ (Figure 1b). Reversible SPMs targeting hydrophobic, more-inert amino acid residues are much rarer. The hypervalent iodine (III) reagent developed by Gaunt selectively reacted with Met, and the sulfonium products of this forward reaction regenerated Met by reductive treatment with tris(2-carboxyethyl)phosphine (TCEP) (Figure 1c). ${ }^{20}$ Ball developed a unique conjugation method at Tyr involving $\eta^{6}$-arene complex formation of the Tyr phenol with a cationic rhodium(III) species. ${ }^{50}$ This complex was deconjugated by treatment with dithiothreitol (DTT) or hydrogen peroxide (Figure 1d). These seminal studies on more-inert amino acids, however, did not address whether protein function was recovered after deconjugation. Reversible SPMs will enable on-demand control of protein function. However, molecular design principles accommodating both stability and cleavability for protein conjugates are still limited. Much of the bond cleavage chemistry is not compatible with mild, nearphysiological, conditions (neutral $\mathrm{pH}$ at ambient temperature in aqueous media) and functional group-enriched circumstances. $^{51-55}$

Tyrosine (Tyr) exists in low abundance in protein primary sequences $(\sim 3.0 \%),{ }^{56}$ but is moderately exposed on protein surface due to amphiphilicity of the phenol functional group. Surface Tyr is often involved in protein functions in a variety of ways, as a target of PTM phosphorylation as well as a crucial functional motif for enzyme-substrate or protein-protein interactions (PPIs) ${ }^{57}$ Therefore, Tyr-selective SPMs can dramatically affect protein functions. There are several examples for Tyr-selective SPMs complementary to enzymatic methodologies $^{58-62}$ : e.g. Barbas ${ }^{63,64}$ reported ortho- $C$-functionalization of the Tyr phenol with triazolinediones, which was later advanced further to enzymatic and electrochemical Tyr SPMs by Nakamura $^{65-69}$ and Gouin ${ }^{70}$, respectively. Lei ${ }^{71}$ and MacMillan ${ }^{72}$ also developed electrochemical and photochemical ortho- $C$-functionalization for Tyr SPMs, respectively, using phenothiazine derivatives. For $O$-functionalization, Francis ${ }^{73}$ and Lee/Kim ${ }^{74}$ reported a palladium-complex-mediated allylic substitution and sulfur fluoride exchange chemistry (SuFEx), respectively. As described above, Ball ${ }^{50}$ developed a reversible Tyr modification (Figure 1d). Herein, we describe a Tyr-selective SPM using persistent iminoxyl radicals (Figure 1e), enabling dynamic control of protein function through reversible covalent bond formation and cleavage. The steric and electronic demands of iminoxyl radicals influence their thermodynamic stability and reversibility, constituting a molecular principle for the stability and cleavability of protein conjugates. 
(a) $(\mathrm{Y}=\mathrm{S}, \mathrm{N})$
Cys/His

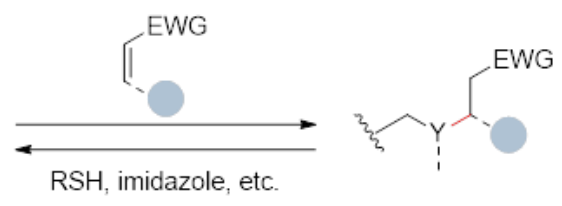

(b)

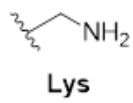

(c)

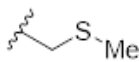

Met

(d)

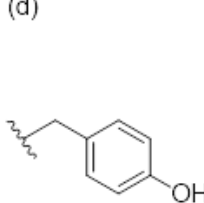

Tyr
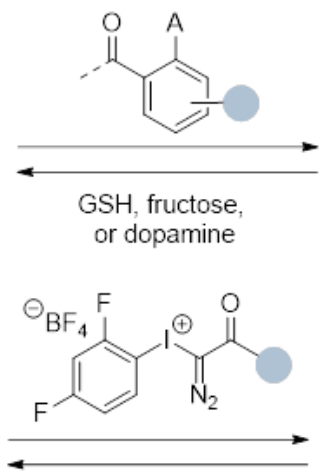

TCEP

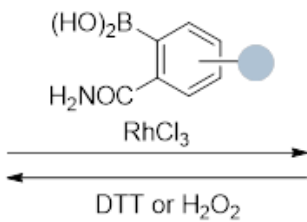

DTT or $\mathrm{H}_{2} \mathrm{O}_{2}$

\begin{abstract}
(1)
\end{abstract}
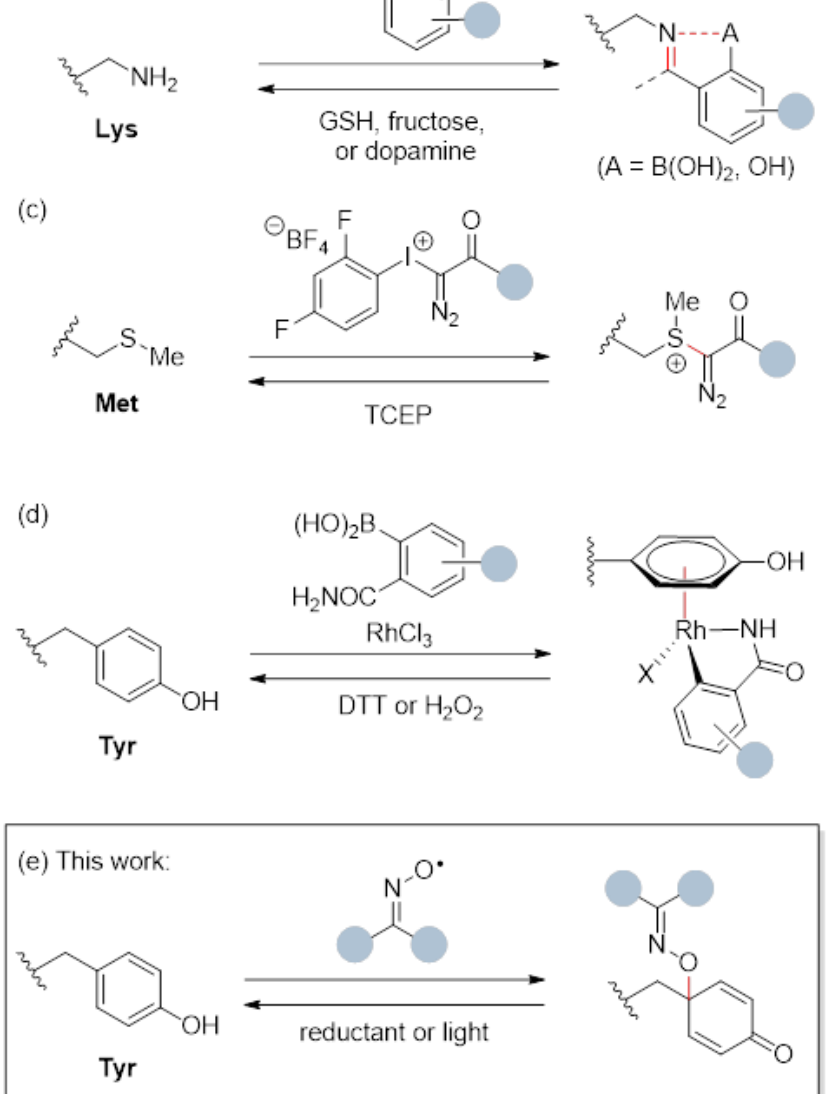

Figure 1. Representative precedents for reversible synthetic protein modifications (SPMs).

\section{Results}

Optimization of Tyr-Selective Modification with Iminoxyl Radicals. Identifying orthogonal reactivity of aminoxyl radicals to water and various polar functional groups, ${ }^{75-78}$ we previously developed a Trp-selective SPM using a sterically less-hindered and electronically activated persistent aminoxyl radical, keto-ABNO. ${ }^{78} \mathrm{We}$ are also interested in properties and reactivity of iminoxyl radicals, an alternative group of persistent $N$-oxyl radicals unexplored in SPM. ${ }^{79}$ Mendenhall and coworkers reported a conjugation reaction between $p$-cresol and di-tert-butyl iminoxyl radical, which was generated in situ via one-electron oxidation of oxime 1e with ceric ammonium nitrate (CAN; Figure 2a). ${ }^{80}$ Based on this report and our research experiences, we began to develop a novel SPM platform using iminoxyl radicals at the Tyr phenol.
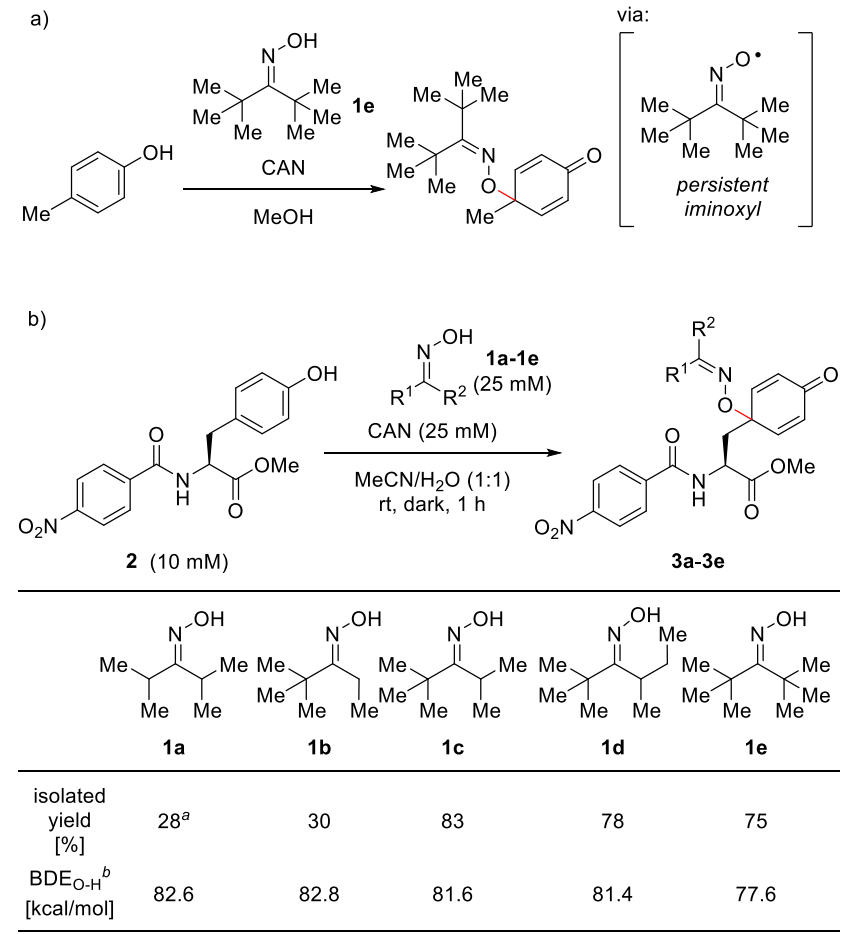

Figure 2. Effects of oximes' steric and electronic factors on reactivity. (a) Oxidative coupling between oxime 1e and $p$-cresol through di- $t \mathrm{Bu}$ iminoxyl radical, reported by Mendenhall. ${ }^{80}$ (b) Comparison of oximes. Reaction conditions: substrate $2(0.5 \mathrm{mmol}$, $10 \mathrm{mM}$ ), oxime 1 (1.25 mmol, $25 \mathrm{mM})$, and CAN (1.25 mmol, 25 $\mathrm{mM})$ in $\mathrm{MeCN} / \mathrm{H}_{2} \mathrm{O}(1: 1)$ at room temperature in the dark for $1 \mathrm{~h}$. ${ }^{a}$ Reaction time was 0.5 h. ${ }^{b} \mathrm{BDE}_{\mathrm{O}-\mathrm{H}}$ (for $E$-isomer of $\mathbf{1 b}, \mathbf{1 c}$, and 1d) was calculated using DFT [(RO)B3LYP/6-311+G(2d, 2p)//(U)B3LYP/6-31G(d)]. ${ }^{84}$

We first examined oxidative coupling of oximes 1 bearing systematically altered substituents with $N$ - $p$-nitrobenzoyl-L-tyrosine methyl ester (2) in an acetonitrile $(\mathrm{MeCN}) / \mathrm{H}_{2} \mathrm{O}$ mixed solvent (Figure $2 b$ ). When oximes $1 \mathbf{a}-\mathbf{1 e}, \mathrm{CAN}$, and $\mathbf{2}$ were reacted in the dark, corresponding oxime adducts $\mathbf{3 a}-\mathbf{3 e}$ were obtained. All the oxime adducts were stable enough for purification by silica gel chromatography. Steric and electronic factors of oximes correlated with yield of the products; sterically less hindered oximes $\mathbf{1 a}$ and $\mathbf{1 b}$ resulted in lower yield than bulkier oximes 1c-1e, with intermediate-size oxime 1c affording the highest yield $(83 \%)$. The observed tendency is likely due to the balance between stability and reactivity of iminoxyl radicals, ${ }^{81-}$ ${ }^{83}$ which are in part dictated by the bond dissociation energy $\left(\mathrm{BDE}_{\mathrm{O}-\mathrm{H}}\right)$ of oximes' $\mathrm{O}-\mathrm{H}$ bonds. ${ }^{84}$ The conversion of oximes to iminoxyl radicals is facile for $\mathbf{1 a - 1 e}$, due to the great oxidation potential of CAN. Sterically less demanding iminoxyl radicals $\mathbf{1 a}$ and $\mathbf{1 b}$ are, however, prone to deactivation through selfdimerization. ${ }^{81,82,85}$ Therefore, the concentration of iminoxyl radicals is higher according to the steric demands. Due to steric repulsion, however, the reactivity of iminoxyl radicals with the phenol group is lesser according to the steric demands $(\mathbf{1 c}>\mathbf{1 d}$ $>$ 1e). Higher stability of sterically more demanding iminoxyl radicals due to the increased hyperconjugation by electron-donating methyl groups, which reflects to smaller BDE values, also contribute to the observed reactivity order.

To apply the reaction to peptides and proteins, we then further optimized the oxime structure using water-soluble peptide 4 containing a coumarin dye at the $N$-terminal as a model 
substrate, in an organic solvent-free, neutral buffered medium at $37^{\circ} \mathrm{C}$ (Figure 3 ). Yield of adduct 5 was quantitatively evaluated by HPLC. The reaction of 1c with $\mathbf{4}$ proceeded only in moderate yield (38\%), likely due to the low water-solubility of 1c. Thus, we examined water-soluble oximes bearing polar functional groups ${ }^{86}$ (1f-1o, Figure 3, also see Figure S2 for more comprehensive screening results). Among the examined, 1f containing a methyl piperidinium and isopropyl ( $i$ Pr) substituents exhibited the highest yield (83\%). When the piperidinium group was used as a secondary alkyl substituent (1g), yield was lower $(44 \%)$. Maintaining the methyl piperidinium substituent, we investigated the steric effects of the other substituent (1h1o). The reactivity dependence on steric factors was consistent with the bell-shape tendency observed in the simpler system (Figure 2b). Other substitution patterns did not produce superior yields (Figure S2). Overall, for high-yielding Tyr-modification, oxime reagents must fulfil the following three structural requirements: (1) presence of a polar functional group to confer water-solubility, (2) substituent combination to be tert-butyl $(t \mathrm{Bu})$ and $i \operatorname{Pr}$ groups or their equivalents, and (3) non-conjugated oximes.

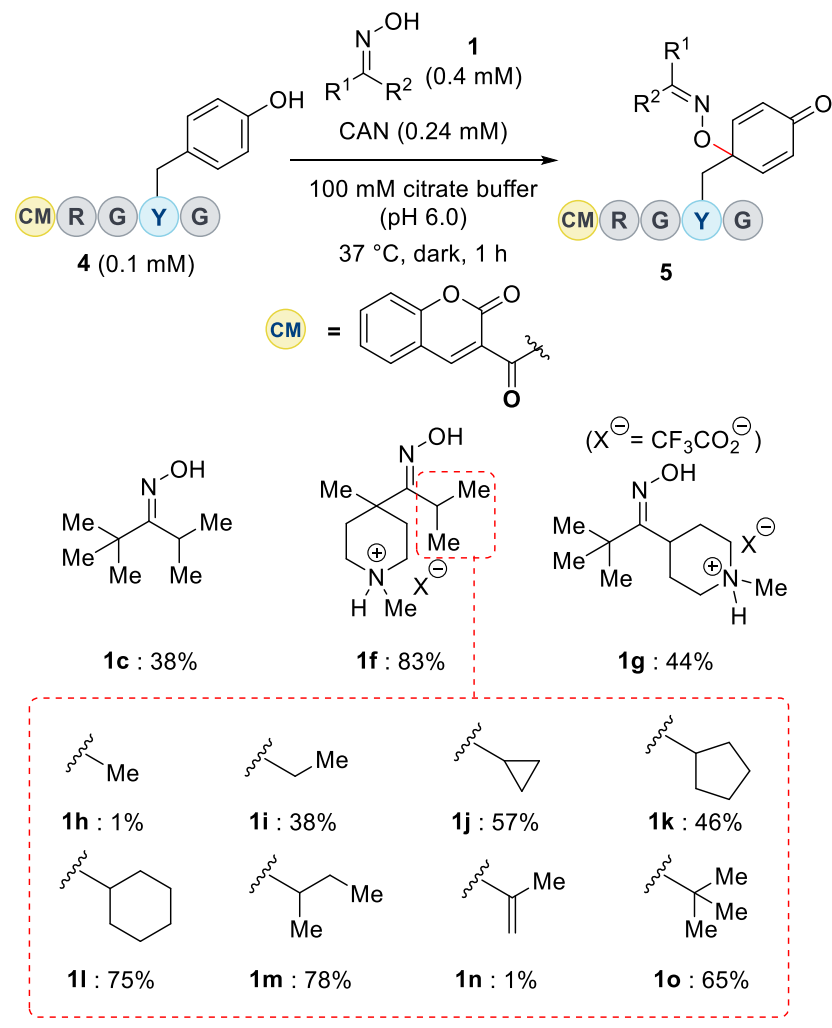

Figure 3. Optimization of oxime structure for Tyr-selective modification in buffered media. Reaction conditions: peptide $4(0.1 \mathrm{mM})$, oxime $1(0.4 \mathrm{mM})$, and CAN $(0.24 \mathrm{mM})$ in $100 \mathrm{mM}$ citrate buffer $\left(\mathrm{pH}\right.$ 6.0) at $37^{\circ} \mathrm{C}$ in the dark for $1 \mathrm{~h}$. HPLC yield was determined from the peak area of $\mathbf{5}$ at $320 \mathrm{~nm}$ detection using sulisobenzone as an internal standard.

Using oxime 1f, we next optimized the reaction conditions (Figure 4). When oxidants other than CAN were used, the reaction did not proceed smoothly and resulted in low yield $(<57 \%$, entry 2; Figure S3). Under white LED irradiation (entry 3 ) or at temperatures lower than $37{ }^{\circ} \mathrm{C}$ (entry 4, 5), yield diminished, especially in the former case $(5 \%)$. The reaction using increased reagent amounts [1f $(1 \mathrm{mM}, 10$ equiv to 4$)$ and CAN $(0.6 \mathrm{mM})$ ] in a $100 \mathrm{mM}$ citrate buffer ( $\mathrm{pH}$ 6.0) afforded product 5 in higher yield (90\%, entry 6). Use of buffers with higher $\mathrm{pH}(\mathrm{pH} 6.7-$ 8.0 ) or buffers other than citrate buffer diminished yield (57$83 \%$, entry $7-9,11,12)$. When unbuffered water was used as a solvent, the reaction medium reached $\mathrm{pH} \sim 4$ due to the acidity of CAN, although the reaction proceeded smoothly (87\%, entry 10). Because direct exposure to CAN was detrimental to some proteins (Figure S4), we identified a premixed procedure of $\mathbf{1 f}$ and CAN taking advantage of persistent nature of the iminoxyl radical. Thus, $\mathbf{4}$ was added after complete consumption of CAN by premixing with 1f for 30 seconds, producing comparable yield ( $85 \%$, entry 13 ) to the mixing-at-once conditions (entry 6).

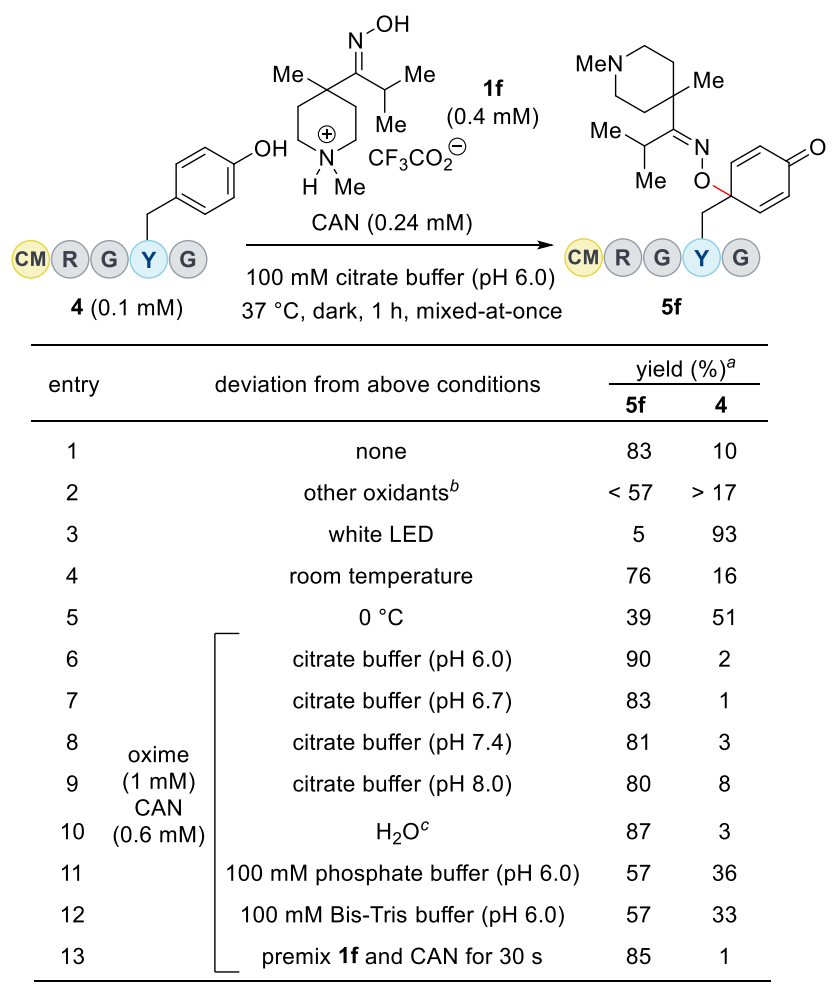

Figure 4. Optimization of reaction conditions. Standard reaction conditions (entry 1$)$ : peptide $4(0.1 \mathrm{mM})$, oxime $1 \mathbf{1 f}(0.4 \mathrm{mM})$, CAN $(0.24 \mathrm{mM})$ in $100 \mathrm{mM}$ citrate buffer (pH 6.0), $37{ }^{\circ} \mathrm{C}$, dark, $1 \mathrm{~h} .{ }^{a}$ Determined by the peak area of HPLC chart $(320 \mathrm{~nm})$ using sulisobenzone as an internal standard. ${ }^{b}$ Yield of 5f: TEMPO ${ }^{+} \mathrm{BF}^{-}$; $57 \%, \mathrm{NaIO}_{4}, \mathrm{NaIO}_{3}, \mathrm{~K}_{2} \mathrm{~S}_{2} \mathrm{O}_{8}, \mathrm{Cu}(\mathrm{OAc})_{2}, \mathrm{~K}_{3}\left[\mathrm{Fe}(\mathrm{CN})_{6}\right], \mathrm{KMnO}_{4}$, $\mathrm{NaNO}_{2}, \mathrm{H}_{2} \mathrm{O}_{2}, \mathrm{NaClO} ; 0 \% .{ }^{c}$ The reaction solution was acidic $(\mathrm{pH}$ $\sim 4$ ).

Under the optimized conditions (Figure 4, entry 13), we examined the amino acid compatibility by the reaction of $\mathbf{4}$ in the presence of an equimolar competitive amino acid $\mathbf{X}$ (Figure 5). The Tyr-modification of $\mathbf{4}$ proceeded smoothly in the presence of amino acids with polar side chains (Lys, Ser), aromatic side chains (His, Phe, Trp), and Cys dimer, with all amino acids recovered in high rates (entry 1-5, 7, Figure S5-S9, S11). When Met was added as $\mathbf{X}$, however, competitive oxidation of the thioether group proceeded and the recovery rate of Met was low $(26 \%)$. Addition of thiourea as an orthogonal reductant to iminoxyl radicals dramatically improved the recovery rate of Met (>99\%, entry 6 in Figure 5, Figure S10). These results showcase high Tyr-selectivity of the iminoxyl radical-mediated modification. 


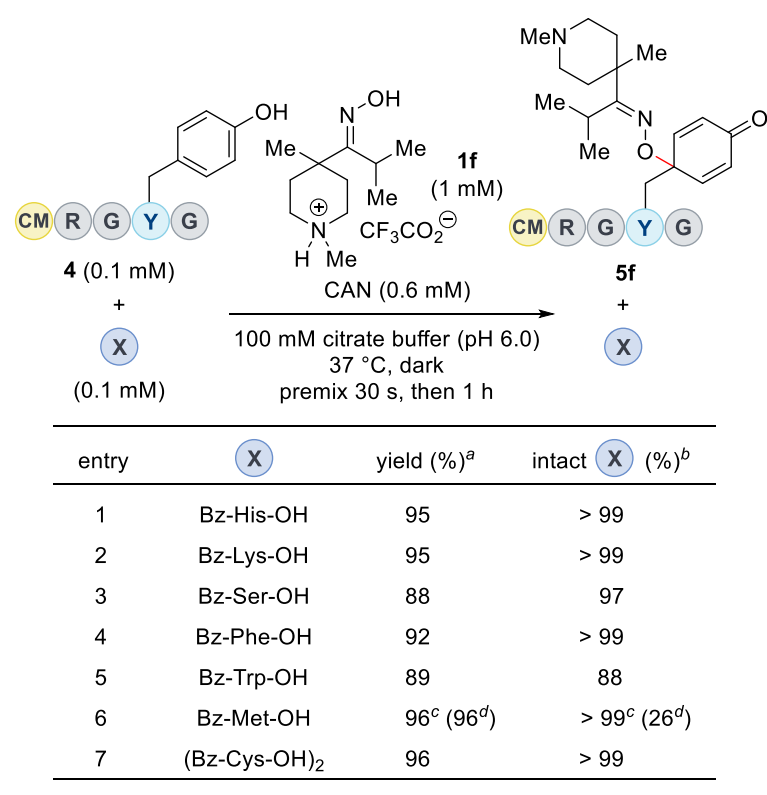

Figure 5. Amino acid compatibility of Tyr-selective modification. Reaction conditions: peptide $\mathbf{4}(0.1 \mathrm{mM})$, amino acid $\mathbf{X}(0.1 \mathrm{mM})$, oxime $1 \mathbf{f}(1 \mathrm{mM}), \mathrm{CAN}(0.6 \mathrm{mM})$ in $100 \mathrm{mM}$ citrate buffer (pH 6.0, $<1 \%$ DMSO), $37{ }^{\circ} \mathrm{C}$, dark, premix 1 and CAN for $30 \mathrm{~s}$, then conjugation reaction for $1 \mathrm{~h} .{ }^{a}$ Determined by the HPLC peak area (320 $\mathrm{nm}$ ) using sulisobenzone as an internal standard. ${ }^{b}$ Determined by the HPLC peak area $(254 \mathrm{~nm})$ using sulisobenzone as internal standard. ${ }^{c}$ Thiourea $(10 \mathrm{mM})$ was added. ${ }^{d}$ Without thiourea.

Tyr-Selective Peptide- and Protein-Modification with 1fDerived Iminoxyl Radicals. We applied the optimized conditions using oxime 1f to biorelevant peptides containing Tyr (Figure 6). The yield was calculated by HPLC peak areas at the isosbestic point $(272 \mathrm{~nm})$ of Tyr and Tyr-oxime adduct (Figure S12). The reaction proceeded in high efficiency with leuprorelin, angiotensin I, bivalirudin, angiotensin IV, neurotensin, and oxytocin bearing macrocyclic disulfide. Modifications of Leu-enkephalin and kisspeptin-10, which contain Tyr at the $\mathrm{N}$ terminal, produced multiple peaks with mass values consistent with the desired products in HPLC charts (Figure S13-S20). This is due to the formation of cyclized products through a successive intramolecular conjugate addition of the $N$-terminal amino group to the cyclohexadienone moiety, generated after oxime addition (the structure in the bracket in Figure 6). As confirmed by LC-MS analysis, yield of peptide modifications with 1f was generally high.

We next applied the reaction with $\mathbf{1 f}$ to proteins (Figure 7). Lysozyme (14 kDa), insulin $(5.8 \mathrm{kDa})$, concanavalin A (26 $\mathrm{kDa}), \alpha$-chymotrypsinogen A (26 kDa), ribonuclease A (14 $\mathrm{kDa}), \alpha$-lactalbumin $(14 \mathrm{kDa})$, and $\alpha$-chymotrypsin $(25 \mathrm{kDa})$ were modified in good yield. Tyr-selectivity was confirmed by tryptic digestion followed by LC-MS/MS analysis of the conjugates (Figure S21-S27). The reaction was also applicable to anti-HER2 antibody trastuzumab (14.8 kDa) (Figure S28). Extent of modification (yield and modification number) were substrate-dependent, reflecting the reactivity and accessibility of Tyr residues. Retention of the higher order structures of proteins after modification was confirmed by circular dichroism (CD) spectroscopy (Figure S21-S27).

Having established the foundation for Tyr-selective peptideand protein-modifications with the iminoxyl radical derived from oxime 1f, we then applied this method to protein functionalization using 1f-based oximes attached with functional molecules (1p-1u, Figure 8). The nitrogen atom in the methyl piperidinium moiety of $\mathbf{1 f}$ was suitable for attaching various functional molecules without changing the reactivity of the iminoxyl radical. Alkyne (1p) and azide (1q) groups were facilely introduced on ribonuclease A using this method in $74 \%$ and $87 \%$ yield, respectively, which can act as handles for bioorthogonal modifications. As an example, the ribonuclease A-1q adduct was tagged with fluorescein by strain-promoted azide-alkyne cycloaddition (Figure 8a-(ii), 8b, see also Figure S35-S38) ${ }^{87}$ The linkage was sufficiently stable to the reductive treatment with DTT and heating at $95{ }^{\circ} \mathrm{C}$ for $30 \mathrm{~min}$, conditions required for detection by SDS-PAGE. Oximes attached to anticancer agent SN-38 (1r), $N$-acetylglucosamine ( $\beta$-D-GlcNAc, 1s), desthiobiotin (1t), and biotin (1u) were successfully conjugated to proteins in useful yield without damaging the payloads (Figure S29-S33, S35), demonstrating the high functional group tolerance. The binding ability of biotin with streptavidin beads remained after the protein conjugation, as demonstrated by the mock-purification experiment of biotin-modified ribonuclease A from a mixture with cell lysate (Figure 8c). Furthermore, the cyclohexadienone moiety generated from the Tyr side chain after modification can be an alternative handle for another type of biorthogonal transformation, hydrazone formation. Thus, treatment of the ribonuclease A-1f adduct with $p-\left(\mathrm{HO}_{2} \mathrm{C}\right)-\mathrm{C}_{6} \mathrm{H}_{4-}$ $\mathrm{NHNH}_{2}$ in the presence of 4-methoxyanthranilic acid ${ }^{88}$ produced an azobenzene through elimination of the oxime (Figure 8a-(iii), Figure S39-S40). ${ }^{89,90}$ This transformation can be a new approach to introducing an azobenzene switch for the photodynamic control of protein functions, ${ }^{91}$ at the position closest to proteins' main chains possible without relying on genetic manipulation.

Deconjugation. When di-tBu oxime adduct 3e was left on the bench at room temperature, we unexpectedly found that the starting tyrosine derivative 2 was regenerated. Therefore, we investigated the stability of oxime adducts $\mathbf{3 a}-\mathbf{3 e}$ in a $\mathrm{CDCl}_{3}$ solution stored in the dark at room temperature (Figure 9, S41). Adduct 3a decomposed rapidly $\left(t_{1 / 2} \sim 5 \mathrm{~h}\right)$ into unidentified products without regenerating 2 . While adducts $3 \mathbf{b}, \mathbf{3 c}$, and $\mathbf{3 d}$ containing a primary or secondary alkyl group as one of the oxime substituents were sufficiently stable, di- $t \mathrm{Bu}$ oxime adduct 3e deconjugated over time $\left(t_{1 / 2} \sim 110 \mathrm{~h}\right)$ and cleanly regenerated 2 as a dominant product. Furthermore, the deconjugation process of $\mathbf{3 e}$ accelerated under room lighting. The stability of adducts $3 \mathbf{b}-\mathbf{3 e}$ is again correlated to the $\mathrm{BDE}_{\mathrm{O}-\mathrm{H}}$ values $^{84}$ of oximes (Figure 2b), which dictate the stability of iminoxyl radicals. We assume that the deconjugation reaction begins with thermally- or photochemically-promoted homolytic cleavage of the ipso-C-O bond of $\mathbf{3 e}$, followed by reduction of the resulting phenoxy radical.

We also confirmed that adduct $\mathbf{5 o}$ generated from peptide $\mathbf{4}$ and water-soluble oxime 10 (Figure 3), which contains a comparable steric demand to $\mathbf{1 e}$, was successfully deconjugated by the treatment with penicillamine or light irradiation in a buffered medium in a much shorter time $(4 \mathrm{~h})$, while adduct $\mathbf{5 f}$ generated from $\mathbf{4}$ and sterically less demanding $\mathbf{1 f}$ was sufficiently stable (Figure S42). In peptide and protein modifications (i.e., forward reaction), oxime 10 generally produced comparable to slightly lower yield than 1f, except for concanavalin A (Figure $6,7)$. To investigate the generality of the deconjugation reaction, we evaluated regeneration of the original peptide substrates from their oxime adducts with 10 (Figure 10, S43-S50). Oxime 1o-adducts derived from leuprorelin, angiotensin I, bivalirudin, 
angiotensin IV, and neurotensin regenerated the original unmodified peptides through deconjugation by penicillamine in high yield. The 1o-adduct derived from oxytocin, however, did not afford the original peptide. Cleavage of the disulfide bond with penicillamine competed in this case, producing multiple products of unidentified structures. Deconjugation from Leuenkephalin-1o and kisspeptin-10-1o adducts did not proceed at all. Those adducts contained stable cyclized structures at the $\mathrm{N}$ terminal Tyr (see Figure 6), and the adducts were recovered in nearly quantitative yield.

The Tyr-selective and reversible protein modification by the iminoxyl radical derived from oxime 10 enables ON/OFF chemical switching of protein functions. We here demonstrate two such examples, switching enzymatic activity and antibodyantigen binding on and off (Figure 11). Preparing $\alpha$-chymotrypsin-1o adduct, the enzymatic activity for hydrolysis of Bz-Tyr-
OEt to Bz-Tyr-OH was assessed (see SI). The modified $\alpha$-chymotrypsin showed a decreased activity by $42 \%$ compared to $\alpha$ chymotrypsin: the initial reaction rate constants $\left(k_{0}\right)$ were 0.051 $\mathrm{mM} \cdot \mathrm{min}^{-1}$ for the modified enzyme and $0.12 \mathrm{mM} \bullet \mathrm{min}^{-1}$ for unmodified $\alpha$-chymotrypsin (Figure 11b). We identified Tyr228 existing in the substrate-binding pocket as a modification site, based on tryptic digestion and LC-MS/MS analysis (Figure S27). ${ }^{92,93}$ Changes in chemical and physical properties of the substrate binding site may be a reason for the observed smaller kinetics after oxime conjugation. Then, treating the adduct with penicillamine at $37{ }^{\circ} \mathrm{C}$ promoted deconjugation. After $6 \mathrm{~h}$, quantitative regeneration of intact $\alpha$-chymotrypsin was observed by LC-MS (Figure 11a, S51). The enzymatic activity recovered to a comparable level $\left(k_{0}=0.11 \mathrm{mM} \cdot \mathrm{min}^{-1}\right)$ to that of unmodified $\alpha$-chymotrypsin after deconjugation.

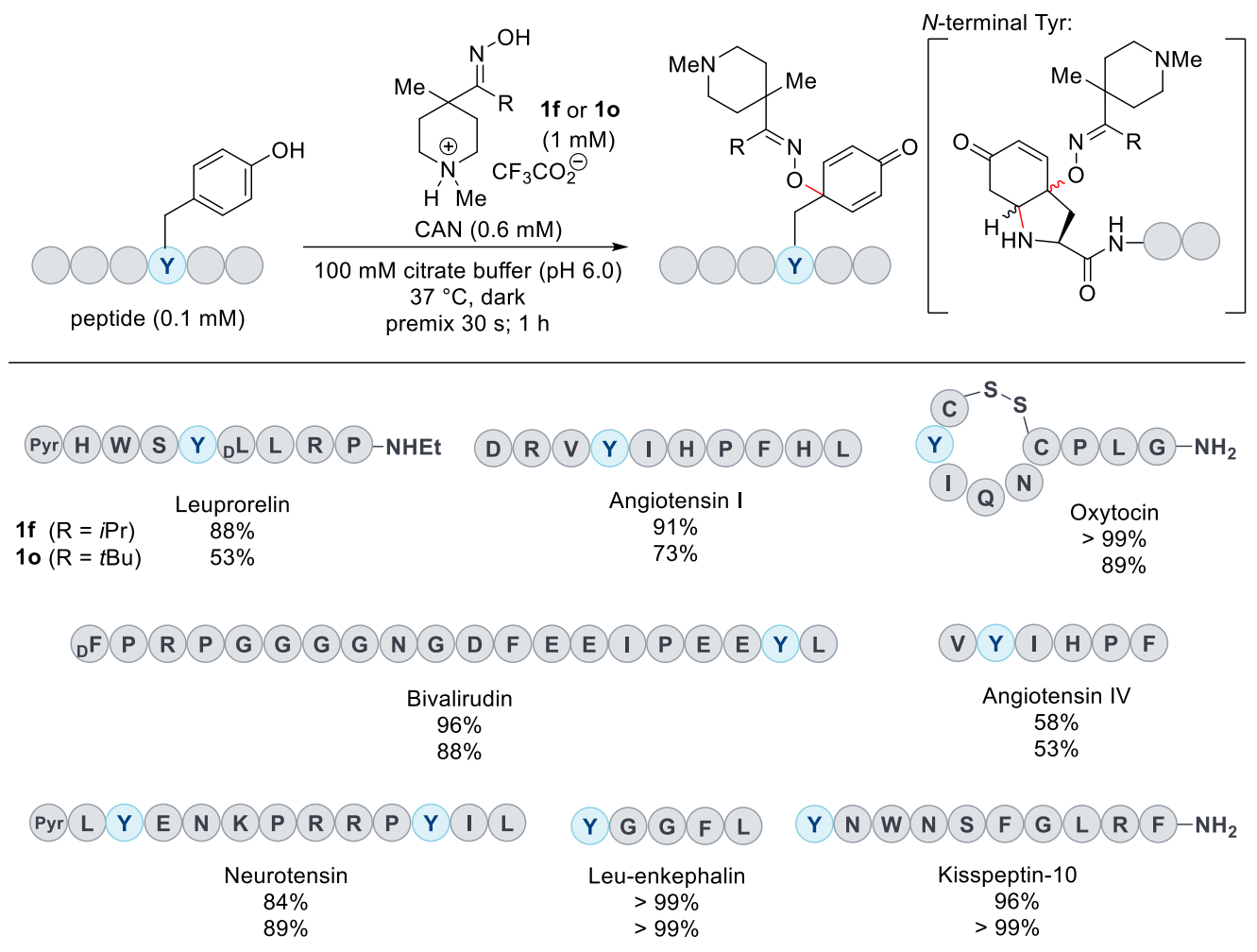

Figure 6. Tyr-selective modification of biorelevant peptides. Reaction conditions: peptide $(0.1 \mathrm{mM})$, oxime 1 f or 10 (1 mM), CAN ( $0.6 \mathrm{mM})$ in $100 \mathrm{mM}$ citrate buffer ( $\mathrm{pH} 6.0), 37^{\circ} \mathrm{C}$, dark, premix $1 \mathbf{1 f}$ or 10 and CAN for $30 \mathrm{~s}$, then conjugation reaction for $1 \mathrm{~h}$. Yield was determined by the HPLC peak area $(272 \mathrm{~nm})$. 


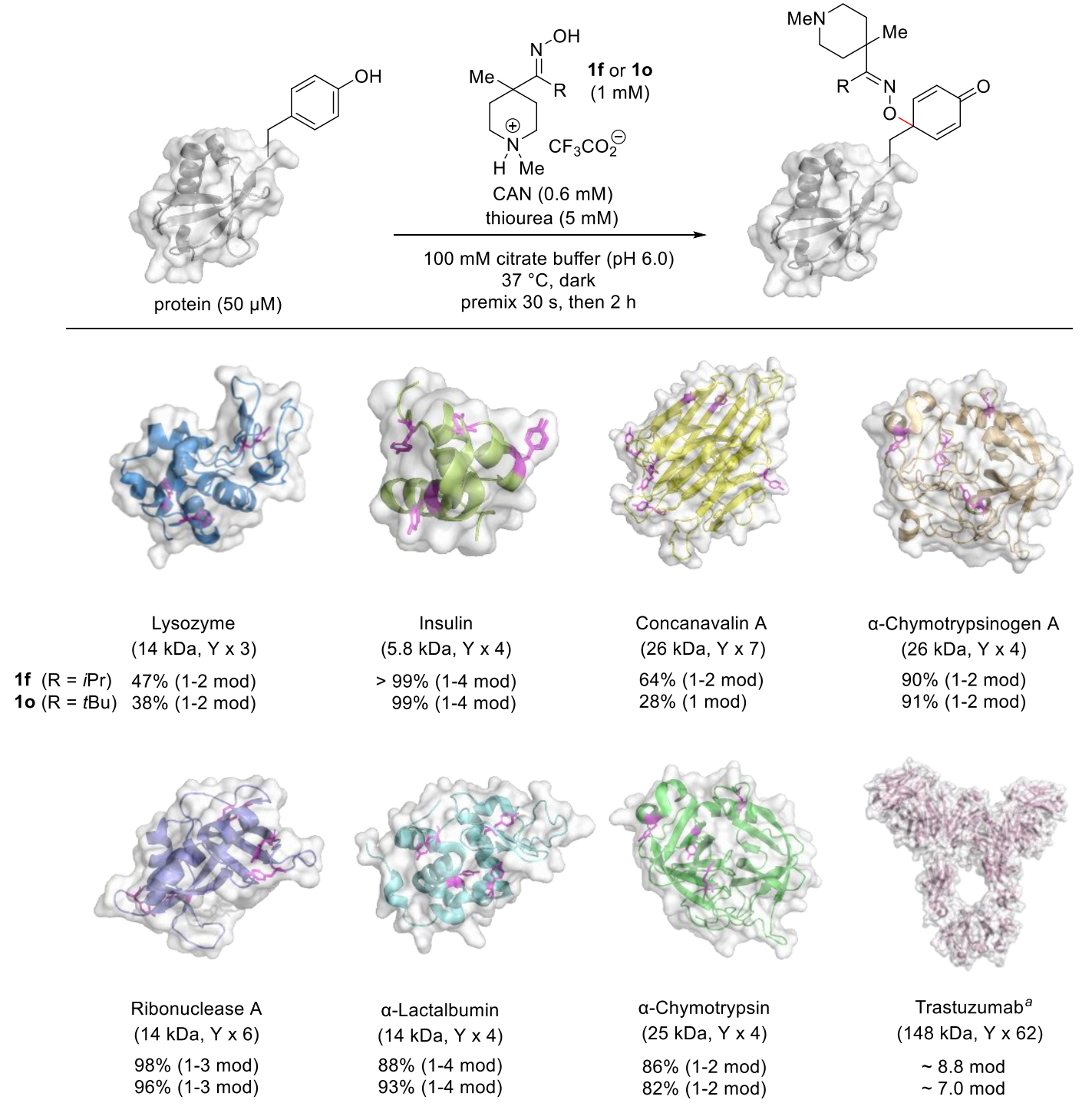

Figure 7. Tyr-selective modification of proteins. Reaction conditions: protein $(50 \mu \mathrm{M})$, oxime 1f or 10 (1 mM), CAN (0.6 mM), thiourea $(5 \mathrm{mM})$ in $100 \mathrm{mM}$ citrate buffer ( $\mathrm{pH} \mathrm{6.0),37}{ }^{\circ} \mathrm{C}$, dark, premix $\mathbf{1 f}$ or 10 and CAN for $30 \mathrm{~s}$ then conjugation reaction for $2 \mathrm{~h}$. Yield was determined by the relative intensity of mass spectrum of corresponding species. Modification number (mod) was determined from LC-MS. ${ }^{a}$ Trastuzumab $(40 \mu \mathrm{M})$, oxime $(2 \mathrm{mM}), \mathrm{CAN}(1.2 \mathrm{mM})$, thiourea $(10 \mathrm{mM})$.

We further examined switching the binding of an antibody, trastuzumab, with HER2 antigen on and off. Tyr residues frequently exist on the surface of the complementarity determining region (CDR) of the antibody and play important roles in antigen-antibody interactions. ${ }^{94,95}$ Therefore, Tyr modification should markedly affect the interactions. Thus, trastuzumab-1o adduct [modification number $(\bmod )=\sim 5.2]$ was prepared and the HER 2 binding activity was assessed by ELISA assay. The affinity of trastuzumab markedly diminished by one-eighth after modification (Figure 11d): $\mathrm{EC}_{50}$ values for unmodified trastuzumab and trastuzumab-1o adduct were $0.37 \mathrm{nM}$ and 2.8 $\mathrm{nM}$, respectively. Treating the adduct with penicillamine, deconjugation proceeded in $15 \mathrm{~h}(\bmod =\sim 1.9$, Figure $11 \mathrm{c})$. The binding affinity was recovered by the deconjugation reaction $\left(\mathrm{EC}_{50}=0.63 \mathrm{nM}\right.$ : Figure $\left.11 \mathrm{~d}\right)$. These results, at least partly, demonstrate that protein functions can be reversibly controlled by Tyr-oxime conjugation and deconjugation under mild, physiologically-relevant conditions. 
(a)
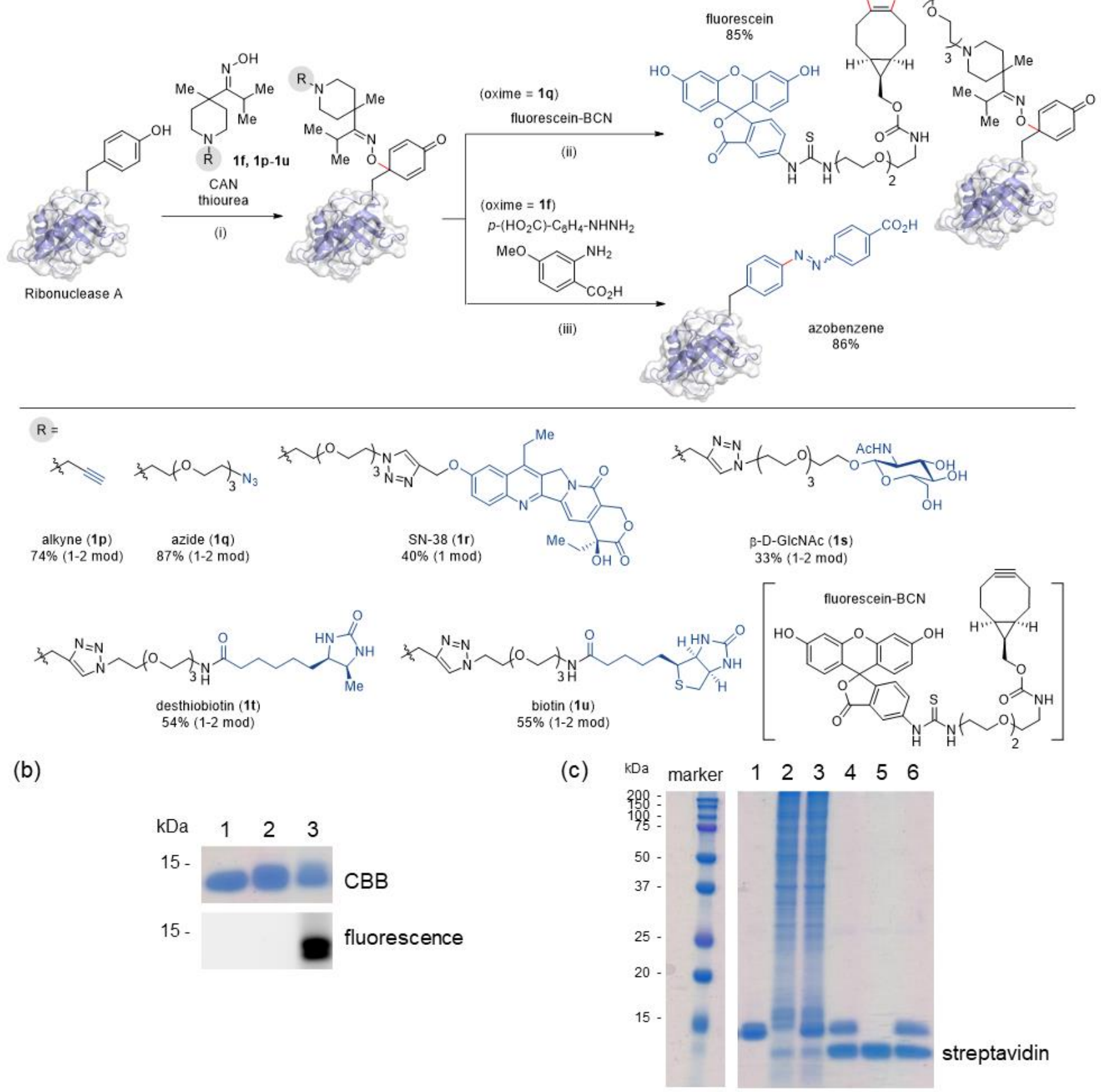

Figure 8. Functionalization of ribonuclease A (RNase A) by Tyr-selective modification. (a) Reaction conditions: (i) RNase A (50 $\mu$ M), oxime $1(1 \mathrm{mM}), \mathrm{CAN}(0.6 \mathrm{mM})$, thiourea $(5 \mathrm{mM})$ in $100 \mathrm{mM}$ citrate buffer $(\mathrm{pH} 6.0), 37{ }^{\circ} \mathrm{C}$, dark, premix of 1f, 1p-1u and CAN for $30 \mathrm{~s}$ then conjugation for $2 \mathrm{~h}$. (ii) Modified RNase A $(25 \mu \mathrm{M})$, fluorescein-BCN $(0.5 \mathrm{mM})$ in 1x PBS (pH 7.4), rt, dark, $12 \mathrm{~h}$. (iii) Modified RNase A $(25 \mu \mathrm{M}), p-\left(\mathrm{HO}_{2} \mathrm{C}\right)-\mathrm{C}_{6} \mathrm{H}_{4}-\mathrm{NHNH}_{2} \cdot \mathrm{HCl}(25 \mathrm{mM})$, 4-methoxyanthranic acid $(2.5 \mathrm{mM})$ in $100 \mathrm{mM}$ citrate buffer (pH 5.0), rt, $21 \mathrm{~h}$. Yield was determined by the relative intensity of mass spectra of corresponding species. (b) SDS-PAGE of RNase A functionalized with fluorescein. CBB staining (up) and fluorescence detection (down). Lane 1: unmodified RNase A, lane 2: RNase A-1q adduct, lane 3: RNase A-1q adduct treated with fluorescein-BCN. (c) SDS-PAGE of pull-down experiments. Biotinylated RNase A (RNase A-1u adduct) was pulled down from its mixture with HeLa S3 cell lysate using streptavidin beads. The band at $13 \mathrm{kDa}$ corresponds to streptavidin released from the beads by boiling. Lane 1: RNase A-1u adduct, lane 2: cell lysate, lane 3: a mixture of cell lysate and RNase A-1u adduct used for the pull down experiment, lane 4: elution from streptavidin beads after pull down from the mixture of cell lysate and RNase A-1u adduct, wash with CRB (50 mM Tris- $\mathrm{HCl}$ (pH 7.5), 0.3\% TritonX-100, $300 \mathrm{mM} \mathrm{NaCl} ; 3$ times), and boiling, lane 5: elution from streptavidin beads treated with cell lysate without RNase A-1u adduct, wash with CRB (3 times), and boiling, lane 6: elution from streptavidin beads treated with RNase A-1u adduct without cell lysate, wash with CRB (3 times), and boiling. 


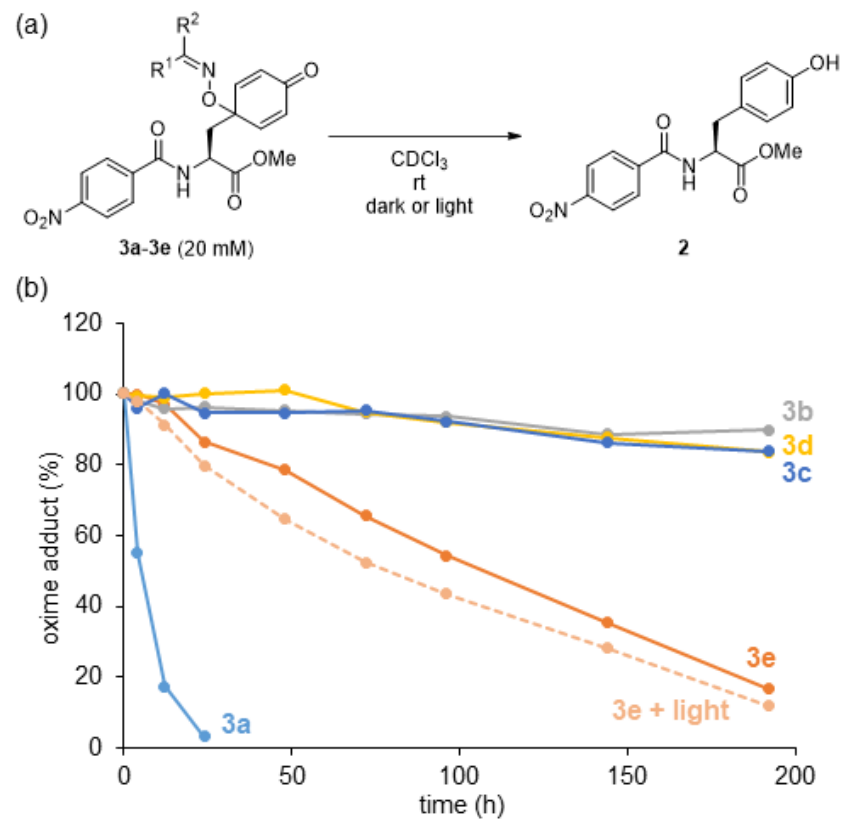

Figure 9. Stability of oxime adducts 3 . The stability was monitored by ${ }^{1} \mathrm{H}$ NMR using 1,1,2,2-tetrachloroethane as an internal standard.

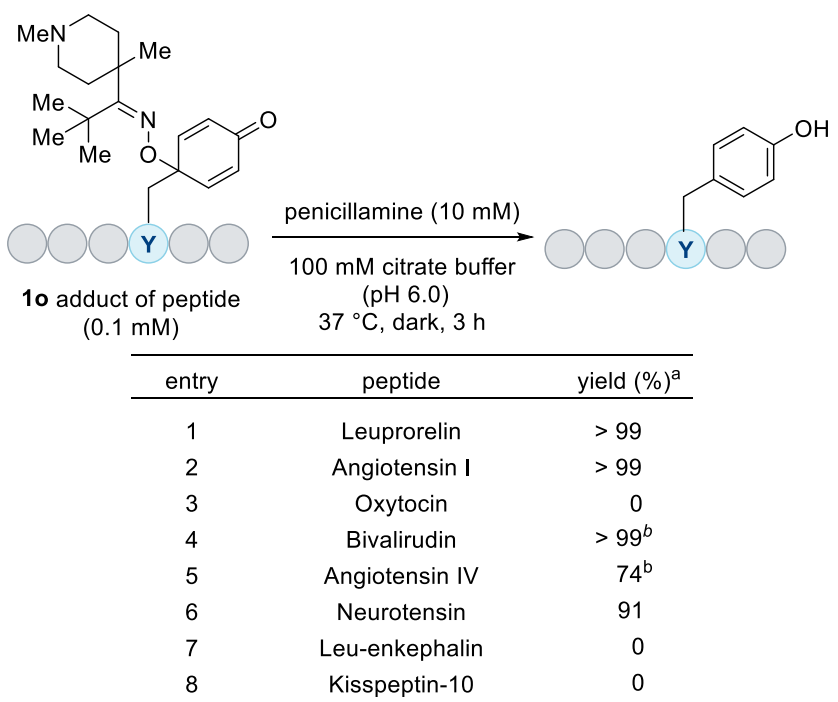

Figure 10. Deconjugation of peptide-1o adducts. Reaction conditions: modified peptide $(0.1 \mathrm{mM})$, penicillamine $(10 \mathrm{mM})$ in 100 mM citrate buffer ( $\mathrm{pH} 6.0$ ), $37^{\circ} \mathrm{C}$, dark, $3 \mathrm{~h} .{ }^{a}$ Yield was determined by the HPLC peak area $(272 \mathrm{~nm}) .{ }^{b}$ Reaction time: $6 \mathrm{~h}$.

\section{Discussion}

Most radical reactions are thermodynamically downhill and thus irreversible due to high reactivity of radicals. Here we found that the reaction between sterically hindered, persistent iminoxyl radicals and the phenol functional group of Tyr can be reversible. The reversibility is tunable by modifying the steric and electronic demands of iminoxyl radicals and reaction conditions. Specifically, substitution of a hydrogen atom to a methyl group at the $\alpha$-position of iminoxyl radicals had profound effects on their reactivity and reversibility (Figure 2b, 9): an Etsubstituted iminoxyl radical (from oxime 1b) was too unstable to be used in conjugation reactions, an $i$ Pr-substituted iminoxyl radical (from 1c) afforded stable conjugates in high yield, and a $t$ Bu-substituted iminoxyl radical (from 1e) furnished reversibility. This tendency can be attributed to stabilization of the electrophilic radical by facile hyperconjugation of alkyl groups. ${ }^{81}$ Steric factors also contribute to the prevention of deactivation of iminoxyl radicals through dimerization and facile homolytic cleavage of the ipso- $\mathrm{C}-\mathrm{O}$ bond in the dearomatized conjugation products. These properties are partly dictated by $\mathrm{BDE}_{\mathrm{O}-\mathrm{H}}$.

The reversibility of the reaction allowed for on-demand caging and decaging of tyrosine residues, which are often crucial for various protein functions. As showcases, we demonstrated reversible regulation of enzymatic activity and antibody-antigen interactions. One of the mechanisms for controlling protein functions in living systems is reversible PTMs mediated by enzymes. There is no example, however, that can mimic reversible PTMs by abiotic chemical reactions under physiological conditions, either in cells or test tubes. Although there are many hurdles before realizing abiotic reversible PTMs intervening into the chemical order of living systems, our reaction may be a step forward to such a research area. Further studies are needed, especially for developing a more biocompatible "on-site" oxidation method for activation of the oxime precursors under physiological conditions. A more realistic application in the shorter term may be decaging functions of biologics or small-molecular drugs depending on local redox states in living organisms. It is known that cancer cells in progressive solid tumors experience hypoxia. ${ }^{96}$ As we demonstrated in this paper, the caged antigenbinding ability of an antibody can be restored by reductive decaging with a thiol. Our method may be useful for selective activation of anticancer biologics or cytotoxic drugs under a local reducing, hypoxic environment. Prodrugging antibodies is an emerging research area, which can promise new theranostics. ${ }^{97}$ Current antibody prodrugging methods, however, have mostly relied on elaborate protein engineering. There are few chemical methods for prodrugged antibodies without altering their primary sequences. A representative is Lys-caging with photolabile protecting groups ${ }^{98-100}$ and phosphatase decaging at Cys. ${ }^{101}$ Due to the requirement of UV irradiation for decaging and randomness and low abundance of Lys in the CDR region, ${ }^{93}$ however, the extent of functional ON/OFF switching has been moderate. The reversible Tyr modification developed here may produce prodrugged antibodies with sharp responses to the local redox environment. 
(a)
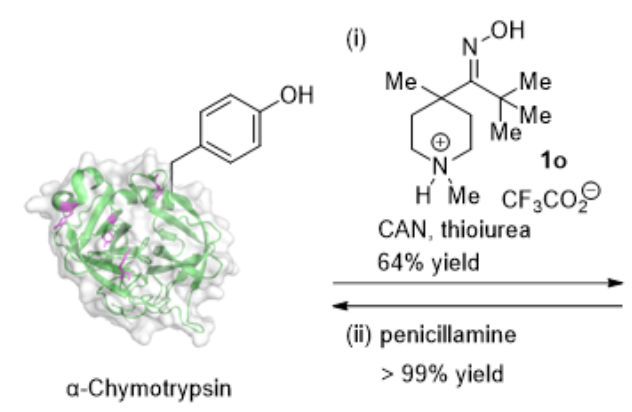

(ii) penicillamine

$>99 \%$ yield

(c)

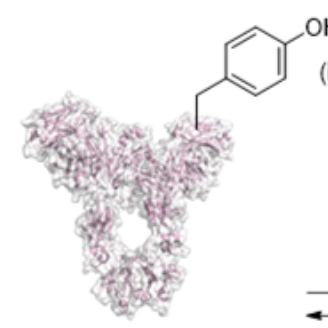

Trastuzumab

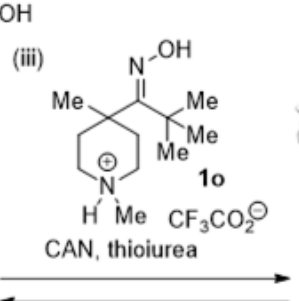

(iv) penicillamine

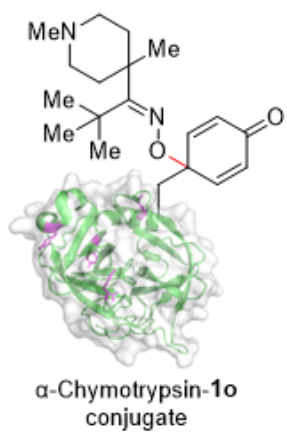

conjugate (b)

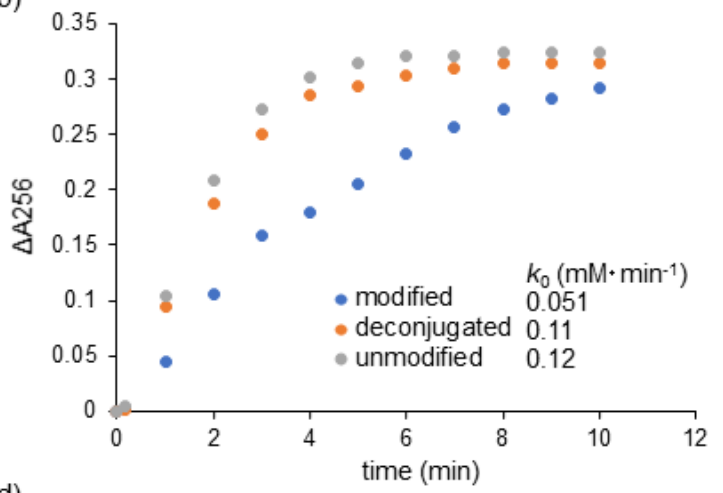

(d)

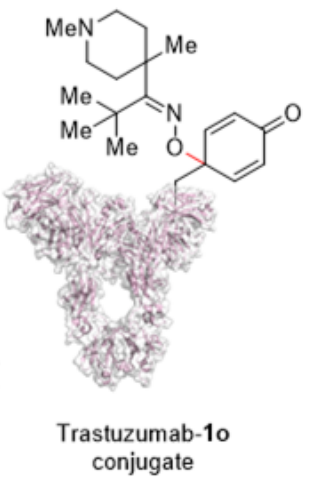

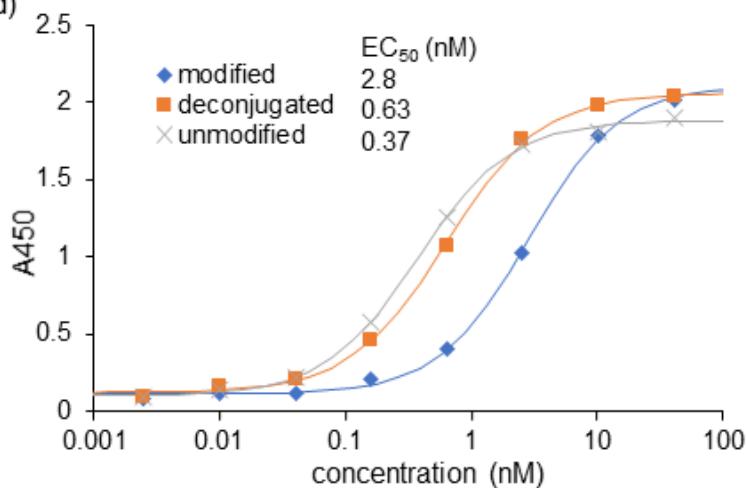

Figure 11. ON/OFF switching of protein functions by reversible Tyr modification. (a) Conjugation of $\alpha$-chymotrypsin with oxime 1o and deconjugation of the adduct. Reaction conditions: (i) $\alpha$-Chymotrypsin $(50 \mu \mathrm{M})$, oxime $10(1 \mathrm{mM})$, CAN $(0.6 \mathrm{mM})$, thiourea $(5 \mathrm{mM})$ in 100 $\mathrm{mM}$ citrate buffer ( $\mathrm{pH} 6.0$ ), $37{ }^{\circ} \mathrm{C}$, dark, premix 10 and CAN for $30 \mathrm{~s}$, then reaction for $2 \mathrm{~h}$. (ii) $\alpha$-Chymotrypsin-1o adduct (12.5 $\mu \mathrm{M}$ ), penicillamine $(1.25 \mathrm{mM}), 37^{\circ} \mathrm{C}, 6 \mathrm{~h}$. Yield was determined by the relative intensity of mass spectra of corresponding species. (b) Comparison of enzymatic activity by hydrolytic rate of Bz-Tyr-OEt to Bz-Tyr-OH. The reaction progress was monitored by the increase of absorbance at $256 \mathrm{~nm}(\Delta \mathrm{A} 256) . k_{0}\left(\mathrm{mM} \bullet \mathrm{min}^{-1}\right)$ was calculated based on the initial reaction rate. (c) Conjugation of trastuzumab with oxime 10 and deconjugation of the adduct. Reaction conditions: (iii) Trastuzumab $(50 \mu \mathrm{M})$, oxime $10(2.5 \mathrm{mM})$, CAN $(1.5 \mathrm{mM})$, thiourea (12.5 mM) in $100 \mathrm{mM}$ citrate buffer ( $\mathrm{pH} \mathrm{6.0),} 37^{\circ} \mathrm{C}$, dark, premix 10 and CAN for $30 \mathrm{~s}$, then reaction for $1 \mathrm{~h}$. (iv) Trastuzumab-1o adduct (10 $\mu \mathrm{M}$ ), penicillamine $(1 \mathrm{mM})$, dark, $37^{\circ} \mathrm{C}, 15 \mathrm{~h}$. (d) Comparison of binding affinity with fixed HER2 determined by ELISA (see SI for experimental details).

\section{Conclusion}

In conclusion, we developed a Tyr-selective peptide- and protein-modification with persistent iminoxyl radicals, conveniently generated from oxime precursors by pretreatment with CAN. The reaction proceeded in high yield under physiologically-relevant buffered conditions. Using water-soluble oxime 1 f or 10 with a slight structural difference, the adduct was either stable or cleanly deconjugated by treatment with a thiol reductant: the reaction using oxime $\mathbf{1 f}$ enabled conjugation of various functional molecules to proteins by the forward reaction, whereas the reversible reaction using oxime 10 could switch protein function on and off. The protein-oxime $\mathbf{1 f}$ adduct contains a reactive cyclohexadienone functional group, which acts as a handle for introducing azobenzene functionality to proteins. Further application of this method in biological research is currently ongoing.

\section{ASSOCIATED CONTENT}

Supporting Information. Experimental procedures, characterization data, computational procedure, and data. The Supporting Information is available free of charge at https://pubs.acs.org.

\section{AUTHOR INFORMATION}

\section{Corresponding Author}

Kounosuke Oisaki - Graduate School of Pharmaceutical Sciences, The University of Tokyo, 7-3-1 Hongo, Bunkyo-ku, Tokyo 1130033, Japan; orcid.org/0000-0002-0499-8168; Email: oisaki@g.ecc.u-tokyo.ac.jp

Motomu Kanai - Graduate School of Pharmaceutical Sciences, The University of Tokyo, 7-3-1 Hongo, Bunkyo-ku, Tokyo 1130033, Japan; orcid.org/0000-0003-1977-7648; Email: motomukanai@g.ecc.u-tokyo.ac.jp

\section{Author Contributions}

K.M., K.O., and M.K. conceived and designed the study. K.M.. T.I., Y.S., and T.T. carried out all experimental work and collected the data. K.S. carried out the computational work. K. M., T.T., K.O. and M.K. analyzed the data. K.M., K.O., and M.K. co-wrote the manuscript.

\section{Funding Sources}

This work was supported in part by JSPS KAKENHI Grant Number JP20H00489 (for M.K.), JSPS KAKENHI Grant Numbers JP18H04239, 25460008, JP18K06545, and JP21H05077, Fugaku Trust for Medical Research, Astellas Foundation for Research on Metabolic Disorders, Research Grant from Noguchi Institute, Kobayashi Foundation for Cancer Research (for K.O.), Iwadare Scholarship Foundation and JSPS Fellowship JP21J14479 (for K.M.), JSPS Fellowship JP15J11454 (for Y.S.), Iwadare Scholarship 
Foundation and JSPS Fellowship JP19J23157 (for K.S.), Worldleading Innovative Graduate Study Program (WINGS) (for T.T.).

\section{Notes}

The authors declare no competing financial interest.

\section{ACKNOWLEDGMENT}

The computational work was performed at the Research Center for Computational Science, Okazaki, Japan. We thank Prof. Yohei Sohma and Dr. Daisuke Sasaki (Wakayama Medical University) for their fruitful discussion.

\section{ABBREVIATIONS}

PTM, post-translational modification; SPM, synthetic protein modification; GSH, glutathione; TCEP, tris(2-carboxyethyl)phosphine; DTT, dithiothreitol; SuFEX, sulfur fluoride exchange; CAN, ceric ammonium nitrate; BDE, bond-dissociation energy; Et, ethyl; $i \mathrm{Pr}$, isopropyl; $t \mathrm{Bu}$, tert-butyl; HPLC, high-performance liquid chromatography; LC-MS, liquid chromatography-mass spectrometry; LCMS/MS, liquid chromatography-tandem mass spectrometry; HER2, human EGFR-related 2; CD, circular dichroism; SDS-PAGE, sodium dodecyl sulphate-polyacrylamide gel electrophoresis; RNase A, ribonuclease A; PBS, phosphate buffer saline; $\mathrm{BCN}$, bicyclo[6.1.0]nonyne; $\mathrm{CBB}$, coomassie brilliant blue, $\mathrm{CRB}$, cell resuspension buffer; CDR, complementarity determining region; ELISA, enzyme-linked immunosorbent assay.

\section{REFERENCES}

(1) Oprea, T. I.; Tropsha, A.; Faulon, J.-L.; Rintoul, M. D. Systems Chemical Biology. Nat. Chem. Biol. 2007, 3 (8), 447-450.

(2) Johnson, E. O.; Hung, D. T. A Point of Inflection and Reflection on Systems Chemical Biology. ACS Chem. Biol. 2019, 14 (12), 2497-2511.

(3) Walsh, C. Posttranslational Modification of Proteins: Expanding Nature's Inventory; Roberts and Company Publishers, 2006.

(4) Verdin, E.; Ott, M. 50 Years of Protein Acetylation: From Gene Regulation to Epigenetics, Metabolism and Beyond. Nat. Rev. Mol. Cell Biol. 2015, 16 (4), 258-264.

(5) Wang, Z. A.; Cole, P. A. The Chemical Biology of Reversible Lysine Post-Translational Modifications. Cell Chem. Biol. 2020, 27 (8), 953-969.

(6) Shi, Y. Serine/Threonine Phosphatases: Mechanism through Structure. Cell 2009, 139 (3), 468-484.

(7) Hunter, T. Tyrosine Phosphorylation: Thirty Years and Counting. Curr. Opin. Cell Biol. 2009, 21 (2), 140-146.

(8) Ardito, F.; Giuliani, M.; Perrone, D.; Troiano, G.; Lo Muzio, L. The Crucial Role of Protein Phosphorylation in Cell Signaling and Its Use as Targeted Therapy (Review). Int. J. Mol. Med. 2017, 40 (2), 271-280.

(9) Koniev, O.; Wagner, A. Developments and Recent Advancements in the Field of Endogenous Amino Acid Selective Bond Forming Reactions for Bioconjugation. Chem. Soc. Rev. 2015, 44 (15), 5495-5551.

(10) deGruyter, J. N.; Malins, L. R.; Baran, P. S. Residue-Specific Peptide Modification: A Chemist's Guide. Biochemistry 2017, 56 (30), 3863-3873.

(11) Hoyt, E. A.; Cal, P. M. S. D.; Oliveira, B. L.; Bernardes, G. J. L. Contemporary Approaches to Site-Selective Protein Modification. Nat. Rev. Chem. 2019, 3 (3), 147-171.

(12) Maruyama, K.; Kanai, M. Synthetic Methodology-Driven Chemical Protein Modifications. Chem. Lett. 2019, 48 (11), 1421-1432.

(13) Shadish, J. A.; DeForest, C. A. Site-Selective Protein Modification: From Functionalized Proteins to Functional Biomaterials. Matter 2020, 2 (1), 50-77.

(14) Tamura, T.; Hamachi, I. Chemistry for Covalent Modification of Endogenous/Native Proteins: From Test Tubes to Complex Biological Systems. J. Am. Chem. Soc. 2019, 141 (7), 2782-2799.
(15) Nozaki, T.; Kanai, M. Chemical Catalysis Intervening to Histone Epigenetics. Acc. Chem. Res. 2021, 54 (9), 2313-2322.

(16) Alvarez Dorta, D.; Deniaud, D.; Mével, M.; Gouin, S. G. Tyrosine Conjugation Methods for Protein Labelling. Chem. Eur. J. 2020, 26 (63), 14257-14269.

(17) Szijj, P. A.; Kostadinova, K. A.; Spears, R. J.; Chudasama, V. Tyrosine Bioconjugation - an Emergent Alternative. Org. Biomol. Chem. 2020, 18 (44), 9018-9028.

(18) Hu, J.-J.; He, P.-Y.; Li, Y.-M. Chemical Modifications of Tryptophan Residues in Peptides and Proteins. J. Pept. Sci. 2021, 27 (1), e3286.

(19) Lin, S.; Yang, X.; Jia, S.; Weeks, A. M.; Hornsby, M.; Lee, P. S.; Nichiporuk, R. V.; Iavarone, A. T.; Wells, J. A.; Toste, F. D.; Chang, C. J. Redox-Based Reagents for Chemoselective Methionine Bioconjugation. Science 2017, 355 (6325), 597-602.

(20) Taylor, M. T.; Nelson, J. E.; Suero, M. G.; Gaunt, M. J. A Protein Functionalization Platform Based on Selective Reactions at Methionine Residues. Nature 2018, 562 (7728), 563-568.

(21) Kim, J.; Li, B. X.; Huang, R. Y.-C.; Qiao, J. X.; Ewing, W. R.; MacMillan, D. W. C. Site-Selective Functionalization of Methionine Residues via Photoredox Catalysis. J. Am. Chem. Soc. 2020, 142 (51), 21260-21266.

(22) Adusumalli, S. R.; Rawale, D. G.; Singh, U.; Tripathi, P.; Paul, R.; Kalra, N.; Mishra, R. K.; Shukla, S.; Rai, V. Single-Site Labeling of Native Proteins Enabled by a Chemoselective and Site-Selective Chemical Technology. J. Am. Chem. Soc. 2018, 140 (44), 15114 15123.

(23) Peciak, K.; Laurine, E.; Tommasi, R.; Choi, J.-W.; Brocchini, S. Site-Selective Protein Conjugation at Histidine. Chem. Sci. 2019, 10 (2), 427-439.

(24) Nakane, K.; Sato, S.; Niwa, T.; Tsushima, M.; Tomoshige, S.; Taguchi, H.; Ishikawa, M.; Nakamura, H. Proximity Histidine Labeling by Umpolung Strategy Using Singlet Oxygen. J. Am. Chem. Soc. 2021, 143 (20), 7726-7731.

(25) Vantourout, J. C.; Adusumalli, S. R.; Knouse, K. W.; Flood, D. T.; Ramirez, A.; Padial, N. M.; Istrate, A.; Maziarz, K.; deGruyter, J. N.; Merchant, R. R.; Qiao, J. X.; Schmidt, M. A.; Deery, M. J.; Eastgate, M. D.; Dawson, P. E.; Bernardes, G. J. L.; Baran, P. S. SerineSelective Bioconjugation. J. Am. Chem. Soc. 2020, 142 (41), 1723617242.

(26) Shiu, H.-Y.; Chan, T.-C.; Ho, C.-M.; Liu, Y.; Wong, M.-K.; Che, C.-M. Electron-Deficient Alkynes as Cleavable Reagents for the Modification of Cysteine-Containing Peptides in Aqueous Medium. Chem. Eur. J. 2009, 15 (15), 3839-3850.

(27) Smith, M. E. B.; Schumacher, F. F.; Ryan, C. P.; Tedaldi, L. M.; Papaioannou, D.; Waksman, G.; Caddick, S.; Baker, J. R. Protein Modification, Bioconjugation, and Disulfide Bridging Using Bromomaleimides. J. Am. Chem. Soc. 2010, 132 (6), 1960-1965.

(28) Chudasama, V.; Smith, M. E. B.; Schumacher, F. F.; Papaioannou, D.; Waksman, G.; Baker, J. R.; Caddick, S. Bromopyridazinedione-Mediated Protein and Peptide Bioconjugation. Chem. Commun. 2011, 47 (31), 8781-8783.

(29) Nathani, R. I.; Chudasama, V.; Ryan, C. P.; Moody, P. R.; Morgan, R. E.; Fitzmaurice, R. J.; Smith, M. E. B.; Baker, J. R.; Caddick, S. Reversible Protein Affinity-Labelling Using BromomaleimideBased Reagents. Org. Biomol. Chem. 2013, 11 (15), 2408-2411.

(30) Krishnan, S.; Miller, R. M.; Tian, B.; Mullins, R. D.; Jacobson, M. P.; Taunton, J. Design of Reversible, Cysteine-Targeted Michael Acceptors Guided by Kinetic and Computational Analysis. J. Am. Chem. Soc. 2014, 136 (36), 12624-12630.

(31) Arumugam, S.; Guo, J.; Mbua, N. E.; Friscourt, F.; Lin, N.; Nekongo, E.; Boons, G.-J.; Popik, V. V. Selective and Reversible Photochemical Derivatization of Cysteine Residues in Peptides and Proteins. Chem. Sci. 2014, 5 (4), 1591-1598.

(32) Diehl, K. L.; Kolesnichenko, I. V.; Robotham, S. A.; Logan Bachman, J.; Zhong, Y.; Brodbelt, J. S.; Anslyn, E. V. Click and Chemically Triggered Declick Reactions through Reversible Amine and Thiol Coupling via a Conjugate Acceptor. Nat. Chem. 2016, 8 (10), 968-973.

(33) Zhang, Y.; Zhou, X.; Xie, Y.; Greenberg, M. M.; Xi, Z.; Zhou, C. Thiol Specific and Tracelessly Removable Bioconjugation via 
Michael Addition to 5-Methylene Pyrrolones. J. Am. Chem. Soc. 2017, 139 (17), 6146-6151.

(34) Yu, J.; Yang, X.; Sun, Y.; Yin, Z. Highly Reactive and Tracelessly Cleavable Cysteine-Specific Modification of Proteins via 4-Substituted Cyclopentenone. Angew. Chem. Int. Ed. 2018, 57 (36), 11598-11602.

(35) Shindo, N.; Fuchida, H.; Sato, M.; Watari, K.; Shibata, T.; Kuwata, K.; Miura, C.; Okamoto, K.; Hatsuyama, Y.; Tokunaga, K.; Sakamoto, S.; Morimoto, S.; Abe, Y.; Shiroishi, M.; Caaveiro, J. M. M.; Ueda, T.; Tamura, T.; Matsunaga, N.; Nakao, T.; Koyanagi, S.; Ohdo, S.; Yamaguchi, Y.; Hamachi, I.; Ono, M.; Ojida, A. Selective and Reversible Modification of Kinase Cysteines with Chlorofluoroacetamides. Nat. Chem. Biol. 2019, 15 (3), 250-258.

(36) Senkane, K.; Vinogradova, E. V.; Suciu, R. M.; Crowley, V. M.; Zaro, B. W.; Bradshaw, J. M.; Brameld, K. A.; Cravatt, B. F. The Proteome-Wide Potential for Reversible Covalency at Cysteine. Angew Chem. Int. Ed. 2019, 58 (33), 11385-11389.

(37) Li, J.; Deng, J.-J.; Yin, Z.; Hu, Q.-L.; Ge, Y.; Song, Z.; Zhang, Y.; Chan, A. S. C.; Li, H.; Xiong, X.-F. Cleavable and Tunable Cysteine-Specific Arylation Modification with Aryl Thioethers. Chem. Sci. 2021, 12 (14), 5209-5215.

(38) Joshi, P. N.; Rai, V. Single-Site Labeling of Histidine in Proteins, on-Demand Reversibility, and Traceless Metal-Free Protein Purification. Chem. Commun. 2019, 55 (8), 1100-1103.

(39) Maier, K.; Wagner, E. Acid-Labile Traceless Click Linker for Protein Transduction. J. Am. Chem. Soc. 2012, 134 (24), 10169 10173.

(40) Cowell, J.; Buck, M.; Essa, A. H.; Clarke, R.; Vollmer, W.; Vollmer, D.; Hilkens, C. M.; Isaacs, J. D.; Hall, M. J.; Gray, J. Traceless Cleavage of Protein-Biotin Conjugates under Biologically Compatible Conditions. ChemBioChem 2017, 18 (17), 1688-1691.

(41) Cal, P. M. S. D.; Vicente, J. B.; Pires, E.; Coelho, A. V.; Veiros, L. F.; Cordeiro, C.; Gois, P. M. P. Iminoboronates: A New Strategy for Reversible Protein Modification. J. Am. Chem. Soc. 2012, 134 (24), 10299-10305.

(42) Cal, P. M. S. D.; Frade, R. F. M.; Cordeiro, C.; Gois, P. M. P. Reversible Lysine Modification on Proteins by Using Functionalized Boronic Acids. Chem. Eur. J. 2015, 21 (22), 8182-8187.

(43) Akçay, G.; Belmonte, M. A.; Aquila, B.; Chuaqui, C.; Hird, A. W.; Lamb, M. L.; Rawlins, P. B.; Su, N.; Tentarelli, S.; Grimster, N. P.; Su, Q. Inhibition of Mcl-1 through Covalent Modification of a Noncatalytic Lysine Side Chain. Nat. Chem. Biol. 2016, 12 (11), 931-936.

(44) Bandyopadhyay, A.; Gao, J. Iminoboronate-Based Peptide Cyclization That Responds to PH, Oxidation, and Small Molecule Modulators. J. Am. Chem. Soc. 2016, 138 (7), 2098-2101.

(45) Cambray, S.; Gao, J. Versatile Bioconjugation Chemistries of Ortho-Boronyl Aryl Ketones and Aldehydes. Acc. Chem. Res. 2018, 51 (9), 2198-2206.

(46) Dal Corso, A.; Catalano, M.; Schmid, A.; Scheuermann, J.; Neri, D. Affinity Enhancement of Protein Ligands by Reversible Covalent Modification of Neighboring Lysine Residues. Angew. Chem. Int. Ed. 2018, 57 (52), 17178-17182.

(47) Chatterjee, S.; Anslyn, E. V.; Bandyopadhyay, A. Boronic Acid Based Dynamic Click Chemistry: Recent Advances and Emergent Applications. Chem. Sci. 2020, 12 (5), 1585-1599.

(48) Faustino, H.; Silva, M. J. S. A.; Veiros, L. F.; Bernardes, G. J. L.; Gois, P. M. P. Iminoboronates Are Efficient Intermediates for Selective, Rapid and Reversible $\mathrm{N}$-Terminal Cysteine Functionalisation. Chem. Sci. 2016, 7 (8), 5052-5058.

(49) Bandyopadhyay, A.; Cambray, S.; Gao, J. Fast and Selective Labeling of N-Terminal Cysteines at Neutral $\mathrm{PH}$ via Thiazolidino Boronate Formation. Chem. Sci. 2016, 7 (7), 4589-4593.

(50) Ohata, J.; Miller, M. K.; Mountain, C. M.; Vohidov, F.; Ball, Z. T. A Three-Component Organometallic Tyrosine Bioconjugation. Angew. Chem. Int. Ed. 2018, 57 (11), 2827-2830.

(51) Li, J.; Chen, P. R. Development and Application of Bond Cleavage Reactions in Bioorthogonal Chemistry. Nat. Chem. Biol. 2016, 12 (3), 129-137.

(52) Bandyopadhyay, A.; Gao, J. Targeting Biomolecules with Reversible Covalent Chemistry. Curr. Opin. Chem. Biol. 2016, 34, $110-116$
(53) Latocheski, E.; Dal Forno, G. M.; Ferreira, T. M.; Oliveira, B. L.; Bernardes, G. J. L.; Domingos, J. B. Mechanistic Insights into Transition Metal-Mediated Bioorthogonal Uncaging Reactions. Chem. Soc. Rev. 2020, 49 (21), 7710-7729.

(54) Shieh, P.; Hill, M. R.; Zhang, W.; Kristufek, S. L.; Johnson, J. A. Clip Chemistry: Diverse (Bio)(Macro)Molecular and Material Function through Breaking Covalent Bonds. Chem. Rev. 2021, 121 (12), $7059-7121$

(55) Wang, J.; Wang, X.; Fan, X.; Chen, P. R. Unleashing the Power of Bond Cleavage Chemistry in Living Systems. ACS Cent. Sci. 2021, 7 (6), 929-943.

(56) Echols, N.; Harrison, P.; Balasubramanian, S.; Luscombe, N. M.; Bertone, P.; Zhang, Z.; Gerstein, M. Comprehensive Analysis of Amino Acid and Nucleotide Composition in Eukaryotic Genomes, Comparing Genes and Pseudogenes. Nucleic Acids Res. 2002, 30 (11), $2515-2523$

(57) Jones, L. H.; Narayanan, A.; Hett, E. C. Understanding and Applying Tyrosine Biochemical Diversity. Mol. Biosyst. 2014, 10 (5), 952-969.

(58) Struck, A.-W.; Bennett, M. R.; Shepherd, S. A.; Law, B. J. C.; Zhuo, Y.; Wong, L. S.; Micklefield, J. An Enzyme Cascade for Selective Modification of Tyrosine Residues in Structurally Diverse Peptides and Proteins. J. Am. Chem. Soc. 2016, 138 (9), 3038-3045.

(59) Bruins, J. J.; Westphal, A. H.; Albada, B.; Wagner, K.; Bartels, L.; Spits, H.; van Berkel, W. J. H.; van Delft, F. L. Inducible, SiteSpecific Protein Labeling by Tyrosine Oxidation-Strain-Promoted (4 + 2) Cycloaddition. Bioconjug. Chem. 2017, 28 (4), 1189-1193.

(60) Montanari, E.; Gennari, A.; Pelliccia, M.; Manzi, L.; Donno, R.; Oldham, N. J.; Macdonald, A.; Tirelli, N. Tyrosinase-Mediated Bioconjugation. A Versatile Approach to Chimeric Macromolecules. $\mathrm{Bi}$ oconjug. Chem. 2018, 29 (8), 2550-2560.

(61) Marmelstein, A. M.; Lobba, M. J.; Mogilevsky, C. S.; Maza, J. C.; Brauer, D. D.; Francis, M. B. Tyrosinase-Mediated Oxidative Coupling of Tyrosine Tags on Peptides and Proteins. J. Am. Chem. Soc. 2020, 142 (11), 5078-5086.

(62) Lobba, M. J.; Fellmann, C.; Marmelstein, A. M.; Maza, J. C.; Kissman, E. N.; Robinson, S. A.; Staahl, B. T.; Urnes, C.; Lew, R. J.; Mogilevsky, C. S.; Doudna, J. A.; Francis, M. B. Site-Specific Bioconjugation through Enzyme-Catalyzed Tyrosine-Cysteine Bond Formation. ACS Cent. Sci. 2020, 6 (9), 1564-1571.

(63) Ban, H.; Gavrilyuk, J.; Barbas, C. F., III. Tyrosine Bioconjugation through Aqueous Ene-Type Reactions: A Click-like Reaction for Tyrosine. J. Am. Chem. Soc. 2010, 132 (5), 1523-1525.

(64) Ban, H.; Nagano, M.; Gavrilyuk, J.; Hakamata, W.; Inokuma, T.; Barbas, C. F., III. Facile and Stabile Linkages through Tyrosine: Bioconjugation Strategies with the Tyrosine-Click Reaction. Bioconjug Chem. 2013, 24 (4), 520-532.

(65) Sato, S.; Nakamura, H. Ligand-Directed Selective Protein Modification Based on Local Single-Electron-Transfer Catalysis. Angew. Chem. Int. Ed. 2013, 52 (33), 8681-8684.

(66) Sato, S.; Nakamura, K.; Nakamura, H. Tyrosine-Specific Chemical Modification with in Situ Hemin-Activated Luminol Derivatives. ACS Chem. Biol. 2015, 10 (11), 2633-2640.

(67) Sato, S.; Nakamura, K.; Nakamura, H. Horseradish-Peroxidase-Catalyzed Tyrosine Click Reaction. ChemBioChem 2017, 18 (5), 475-478.

(68) Sato, S.; Nakane, K.; Nakamura, H. A Laccase-Catalysed Tyrosine Click Reaction. Org. Biomol. Chem. 2020, 18 (19), 3664 3668.

(69) Sato, S.; Matsumura, M.; Kadonosono, T.; Abe, S.; Ueno, T.; Ueda, H.; Nakamura, H. Site-Selective Protein Chemical Modification of Exposed Tyrosine Residues Using Tyrosine Click Reaction. Bioconjug. Chem. 2020, 31 (5), 1417-1424.

(70) Alvarez-Dorta, D.; Thobie-Gautier, C.; Croyal, M.; Bouzelha, M.; Mével, M.; Deniaud, D.; Boujtita, M.; Gouin, S. G. Electrochemically Promoted Tyrosine-Click-Chemistry for Protein Labeling. J. Am. Chem. Soc. 2018, 140 (49), 17120-17126.

(71) Song, C.; Liu, K.; Wang, Z.; Ding, B.; Wang, S.; Weng, Y.; Chiang, C.-W.; Lei, A. Electrochemical Oxidation Induced Selective Tyrosine Bioconjugation for the Modification of Biomolecules. Chem. Sci. 2019, 10 (34), 7982-7987. 
(72) Li, B. X.; Kim, D. K.; Bloom, S.; Huang, R. Y.-C.; Qiao, J. X.; Ewing, W. R.; Oblinsky, D. G.; Scholes, G. D.; MacMillan, D. W. C. Site-Selective Tyrosine Bioconjugation via Photoredox Catalysis for Native-to-Bioorthogonal Protein Transformation. Nat. Chem. 2021, DOI: 10.1038/s41557-021-00733-y.

(73) Tilley, S. D.; Francis, M. B. Tyrosine-Selective Protein Alkylation Using Pi-Allylpalladium Complexes. J. Am. Chem. Soc. 2006, 128 (4), 1080-1081.

(74) Choi, E. J.; Jung, D.; Kim, J.-S.; Lee, Y.; Kim, B. M. Chemoselective Tyrosine Bioconjugation through Sulfate Click Reaction. Chem. Eur. J. 2018, 24 (43), 10948-10952.

(75) Seki, Y.; Tanabe, K.; Sasaki, D.; Sohma, Y.; Oisaki, K.; Kanai, M. Serine-Selective Aerobic Cleavage of Peptides and a Protein Using a Water-Soluble Copper-Organoradical Conjugate. Angew. Chem. Int. Ed. 2014, 53 (25), 6501-6505.

(76) Seki, Y.; Ishiyama, T.; Sasaki, D.; Abe, J.; Sohma, Y.; Oisaki, K.; Kanai, M. Transition Metal-Free Tryptophan-Selective Bioconjugation of Proteins. J. Am. Chem. Soc. 2016, 138 (34), 10798 10801 .

(77) Ozawa, J.; Tashiro, M.; Ni, J.; Oisaki, K.; Kanai, M. Chemoand Regioselective Oxygenation of $\mathrm{C}\left(s p^{3}\right)$-H Bonds in Aliphatic Alcohols Using a Covalently Bound Directing Activator and Atmospheric Oxygen. Chem. Sci. 2016, 7 (3), 1904-1909.

(78) Sonobe, T.; Oisaki, K.; Kanai, M. Catalytic Aerobic Production of Imines en Route to Mild, Green, and Concise Derivatizations of Amines. Chem. Sci. 2012, 3 (11), 3249-3255.

(79) Krylov, I. B.; Paveliev, S. A.; Budnikov, A. S.; Terent'ev, A. O. Oxime Radicals: Generation, Properties and Application in Organic Synthesis. Beilstein J. Org. Chem. 2020, 16, 1234-1276.

(80) Ngo, M.; Larson, K. R.; Mendenhall, G. D. Free-Radical Reagents. 2. Oxidation and Addition Products from the Reaction of DiTert-Butyliminoxyl with Phenols. J. Org. Chem. 1986, 51 (26), 53905393.

(81) Mendenhall, G. D.; Ingold, K. U. Kinetic Application of Electron Paramagnetic Resonance Spectroscopy. IX. Preparation and Properties of Di-Tert-Butyliminoxy. J. Am. Chem. Soc. 1973, 95 (9), 2963-2971.

(82) Eisenhauer, B. M.; Wang, M.; Brown, R. E.; Labaziewicz, H.; Ngo, M.; Kettinger, K. W.; Mendenhall, G. D. Spectral and Kinetic Measurements on a Series of Persistent Iminoxyl Radicals. J. Phys. Org. Chem. 1997, 10 (10), 737-746.

(83) Eisenhauer, B. M.; Wang, M.; Labaziewicz, H.; Ngo, M.; Mendenhall, G. D. Limitations on the Persistence of Iminoxyls: Isolation of Tert-Butyl 1,1-Diethylpropyl Ketiminoxyl and Related Radicals. J. Org. Chem. 1997, 62 (7), 2050-2053.

(84) Pratt, D. A.; Blake, J. A.; Mulder, P.; Walton, J. C.; Korth, H.-G.; Ingold, K. U. O-H Bond Dissociation Enthalpies in Oximes: Order Restored. J. Am. Chem. Soc. 2004, 126 (34), 10667-10675.

(85) Brokenshire, J. L.; Roberts, J. R.; Ingold, K. U. Kinetic Applications of Electron Paramagnetic Resonance Spectroscopy. VII. Self-Reactions of Iminoxy Radicals. J. Am. Chem. Soc. 1972, 94 (20), 7040-7049.

(86) Although some of the oximes were obtained as a mixture of geometrical isomers, we used the mixture for the reaction as geometrical interconversion of an iminoxyl radical is fast. See also ref 79.

(87) Dommerholt, J.; Schmidt, S.; Temming, R.; Hendriks, L. J. A.; Rutjes, F. P. J. T.; van Hest, J. C. M.; Lefeber, D. J.; Friedl, P.; van Delft, F. L. Readily Accessible Bicyclononynes for Bioorthogonal Labeling and Three-Dimensional Imaging of Living Cells. Angew. Chem. Int. Ed. 2010, 49 (49), 9422-9425.

(88) Crisalli, P.; Kool, E. T. Water-Soluble Organocatalysts for Hydrazone and Oxime Formation. J. Org. Chem. 2013, 78 (3), 1184 1189.

(89) John, A. A.; Ramil, C. P.; Tian, Y.; Cheng, G.; Lin, Q. Synthesis and Site-Specific Incorporation of Red-Shifted Azobenzene Amino Acids into Proteins. Org. Lett. 2015, 17 (24), 6258-6261.

(90) Wang, P.; Cheng, Y.; Wu, C.; Zhou, Y.; Cheng, Z.; Li, H.; Wang, R.; Su, W.; Fang, L. Tyrosine-Specific Modification via a Dearomatization-Rearomatization Strategy: Access to Azobenzene Functionalized Peptides. Org. Lett. 2021, 23 (11), 4137-4141.
(91) Mart, R. J.; Allemann, R. K. Azobenzene Photocontrol of Peptides and Proteins. Chem. Commun. 2016, 52 (83), 12262-12277.

(92) Ma, W.; Tang, C.; Lai, L. Specificity of Trypsin and Chymotrypsin: Loop-Motion-Controlled Dynamic Correlation as a Determinant. Biophys. J. 2005, 89 (2), 1183-1193.

(93) Zsila, F.; Kámán, J.; Bogányi B.; Józsvai, D. Binding of alkaloids into the S1 specificity pocket of $\alpha$-chymotrypsin: Evidence from induced circular dichroism spectra. Org. Biomol. Chem. 2011, 9, 4127-4137.

(94) Fellouse, F. A.; Wiesmann, C.; Sidhu, S. S. Synthetic Antibodies from a Four-Amino-Acid Code: A Dominant Role for Tyrosine in Antigen Recognition. Proc. Natl. Acad. Sci. U. S. A. 2004, 101 (34), 12467-12472.

(95) Ramaraj, T.; Angel, T.; Dratz, E. A.; Jesaitis, A. J.; Mumey, B. Antigen-Antibody Interface Properties: Composition, Residue Interactions, and Features of 53 Non-Redundant Structures. Biochim. Biophys. Acta 2012, 1824 (3), 520-532.

(96) Wilson, W. R.; Hay, M. P. Targeting Hypoxia in Cancer Therapy. Nat. Rev. Cancer 2011, 11 (6), 393-410.

(97) Lucchi, R.; Bentanachs, J.; Oller-Salvia, B. The Masking Game: Design of Activatable Antibodies and Mimetics for Selective Therapeutics and Cell Control. ACS Cent. Sci. 2021, 7 (5), 724-738.

(98) Self, C. H.; Thompson, S. Light Activatable A ntibodies: Models for Remotely Activatable Proteins. Nat. Med. 1996, 2 (7), 817-820

(99) Self, C. H.; Self, A. C.; Smith, J. A.; Self, D. J.; Thompson, S. Light-Directed Activation of Human T-Cells. ChemMedChem 2007, 2 (11), 1587-1590.

(100) Thompson, S.; Dessi, J.; Self, C. H. The Construction and in Vitro Testing of Photo-Activatable Cancer Targeting Folated AntiCD3 Conjugates. Biochem. Biophys. Res. Commun. 2008, 366 (2), 526-531.

(101) Gunnoo, S. B.; Finney, H. M.; Baker, T. S.; Lawson, A. D.; Anthony, D. C.; Davis, B. G. Creation of a gated antibody as a conditionally functional synthetic protein. Nat. Commun. 2014, 5, 4388. 


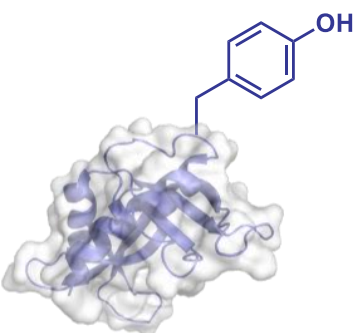

Tyr containing proteins and peptides

- Tyr-selective

Oxime structure-dependent reversibility

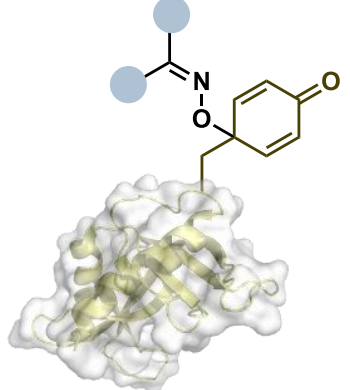

Altered function

Mild reaction conditions

- High functional group tolerance 